\title{
Fecal carriage of multidrug-resistant Escherichia coli by community children in southern Taiwan
}

I-Fei Huang ${ }^{1,2,3 \dagger}$, Wei-Yang Lee ${ }^{4 \dagger}$, Jiun-Ling Wang ${ }^{5,6}$, Chih-Hsin Hung ${ }^{7}$, Hong-Hsiang Hu' ${ }^{1}$, Wan-Yu Hung ${ }^{7}$, Yun-Ju Hung ${ }^{1}$, Wen-Chi Chen ${ }^{2,8}$, Ying-Tso Shen ${ }^{1}$ and Ming-Fang Cheng ${ }^{1,2,9^{*}}$

\begin{abstract}
Background: The emergence of multidrug-resistant (MDR) Escherichia coli (E. coli), particularly E. coli sequence type ST131, is becoming a global concern. Commensal bacteria, an important reservoir of antibiotic resistance genes, facilitate the spread of such genes to pathogenic bacterial strains. The objective of the study is to investigate the fecal carriage of MDR E. coli and ST131 E. coli in community children in Southern Taiwan.

Methods: In this prospective study, stool samples from children aged 0-18 years were obtained within 3 days of hospitalization from October 2013 to September 2014. Children with a history of underlying diseases, antibiotic treatment, or hospitalization in the 3 months before specimen collection were excluded. E. coli colonies were selected and tested for antimicrobial susceptibility, and O25b-ST131, multilocus sequence typing, and blaCTX-M gene groups were detected.

Results: Among 157 E. coli isolates, the rates of nonsusceptibility to ampicillin, amoxycillin + clavulanate, trimethoprimsulfamethoxazole, and cefazolin were 70, 65.6, 47.1, and 32.5\%, respectively. Twenty-nine (18.5\%) isolates were nonsusceptible to ciprofloxacin. MDR E. coli accounted for 58 (37\%) of all isolates. Thirteen (8.3\%) isolates produced extended-spectrum $\beta$-lactamase (ESBL). Furthermore, 26 (16.6\%) and 13 (8.3\%) isolates were O25b and ST131 positive, respectively. Five (38.5\%) of the 13 ESBL-producing E. coli belonged to blaCTX-M group 9, among which were CTXM-14 and 4 (80\%) were O25b-ST131 positive. Compared with the non-ESBL and ciprofloxacin-susceptible groups, the ESBL and ciprofloxacin-nonsusceptible groups showed significantly higher rates of O25b-ST131 positivity.

Conclusions: The prevalence of the fecal carriage of nonsusceptible E. coli in children was high; among these E. coli, $37 \%$ were MDR, 18.5\% were nonsusceptible to ciprofloxacin, and 8.3\% produced ESBL. O25b-ST131 was the most common ESBL-producing E. coli clonal group present in the feces of children, and the ESBL and ciprofloxacin-nonsusceptible groups showed significantly higher rates of O25b-ST131 positivity.
\end{abstract}

Keywords: Escherichia coli, Fecal carriage, Multidrug-resistant, Extended-spectrum $\beta$-lactamase, Children

\section{Background}

The species of the Escherichia genus is heterogeneous, and this genus includes both commensal and pathogenic bacteria. Although only some E. coli are pathological species, they cause infections in various organs, such as the urinary tract, biliary system, and central nervous

\footnotetext{
* Correspondence: mfcheng@vghks.gov.tw

${ }^{\dagger}$ I-Fei Huang and Wei-Yang Lee contributed equally to this work.

'Department of Pediatrics, Kaohsiung Veterans General Hospital, No. 386,

Ta-Chung 1st Road, Kaohsiung 81362, Taiwan

${ }^{2} \mathrm{~S}$ chool of Medicine, National Yang-Ming University, Taipei, Taiwan

Full list of author information is available at the end of the article
}

system, ranging from spontaneously resolving cystitis to life-threatening sepsis syndrome in humans of all ages [1]. Increasing antibiotic resistance results in increased mortality and morbidity, enhances transmission of resistant bacteria, and increases health expenses [2]. The emergence of MDR $E$. coli is becoming a global concern, with particular emphasis on E. coli sequence type ST131, which is increasingly reported in urinary tract infections (UTIs). In 2008, E. coli ST131 was identified as a major clone associated with the spread of CTX-M-15 ESBL resistance [3-5]. Thereafter, E. coli ST131 was also

(c) The Author(s). 2018 Open Access This article is distributed under the terms of the Creative Commons Attribution 4.0 International License (http://creativecommons.org/licenses/by/4.0/), which permits unrestricted use, distribution, and 
strongly associated with fluoroquinolone resistance and co-resistance to aminoglycosides and trimethoprimsulfamethoxazole (TMP-SMZ) [6-8]. Current strategies to monitor antibiotic resistance in bacteria mainly rely on examining resistance in pathogenic organisms [9]. However, commensal bacteria, an important reservoir of antibiotic resistance genes, facilitate the spread of such genes to pathogenic bacterial strains [10, 11]. Humans, companion and noncompanion animals, and foods are established reservoirs of the ST131 E. coli clone [12]. Few studies have investigated fecal carriage of MDR $E$. coli by community children. Therefore, the objective of the study was to investigate the fecal carriage of MDR $E$. coli and ST131 E. coli by community children in Southern Taiwan.

\section{Methods}

\section{Study population}

In this prospective study, children aged $0-18$ years who were admitted to the Pediatric Department of Kaohsiung Veterans General Hospital from October 2013 to September 2014 because of mild febrile illnesses, namely acute respiratory, gastroenteritis, or skin and soft tissue infection, and underwent regular examinations were enrolled. Exclusion criteria were any history of antibiotic treatment or hospitalization in the 3 months before specimen collection and a history of underlying diseases. The study was approved by the Ethics Committee of the Kaohsiung Veterans General Hospital (reference number VGHKS16-CT2-04). All participants (their parent or legal guardian in the case of children aged less than 16 years) provided informed consent. Stool samples were obtained as soon as it was available after admission. All of them were obtained within 3 days of admission [13].

\section{Microbiological laboratory procedures \\ Screening for E. coli strains in stool samples}

Each stool sample was spread on a CHROMagar ${ }^{\text {tix }}$ ECC plate (CHROMagar, Paris, France), which is efficient for the simultaneous enumeration of E. coli [14] and incubated at $37{ }^{\circ} \mathrm{C}$ for $24 \mathrm{~h}$; E. coli strains appeared as blue colonies. A blue colony was picked [14] and added to $1 \mathrm{~mL}$ of sterilized Luria-Bertani medium for serial dilution. A $100-\mu \mathrm{L}$ suspension was subsequently spread on the CHROMagar ${ }^{\text {ru }}$ ECC plate again to identify the E. coli colonies presenting the blue color; 1 colony was selected for further analysis.

\section{Antimicrobial susceptibility testing}

The selected E. coli colony was subjected to antimicrobial susceptibility testing using the Vitek 2 automated system (Vitek AMS; bioMerieux Vitek Systems Inc., Hazelwood, MO, USA) with ID-GN and AST-N277 cards (Durham, NC, USA). The ASTN277 card was used to investigate ESBL production and antimicrobial susceptibility. The breakpoints of antimicrobial agents were determined according to Clinical and Laboratory Standards Institute standards [15]. Each panel had six wells containing cefepime $(1.0 \mu \mathrm{g} / \mathrm{mL})$, cefotaxime $(0.5 \mu \mathrm{g} / \mathrm{mL})$, and ceftazidime $(0.5 \mu \mathrm{g} / \mathrm{mL})$ alone and in combination with clavulanic acid $(10,4$, and $4 \mu \mathrm{g} / \mathrm{mL}$, respectively). The proportional reduction in growth in the wells containing cephalosporin + clavulanic acid compared with that in the wells containing cephalosporin alone was considered indicative of ESBL production. In this study, possible ESBL producers were screened using the M100-S19 (2009) breakpoints for the entire study period (Additional file 1).

MDR was defined as acquired nonsusceptibility to at least 1 agent in 3 or more antimicrobial categories, namely $\beta$-lactam or $\beta$-lactamase inhibitors (ampicillin and amoxicillin-clavunate), cephalosporins (flormoxef, cefazolin, cefuroxime, cefoxitin, cefotaxime, cefatazidime, and cefpirome), carbapenem (ertapenem and imipenem), aminoglycosides (gentamicin and amikacin), fluoroquinolones (ciprofloxacin and moxifloxacin), tigecycline, colistin, and TMP-SMZ [16].

\section{Detection of O25b-ST131, multilocus sequence typing, and blaCTX-M gene groups}

Polymerase chain reaction was performed as previously described [17] to screen for the O25b serotype by using the primers $\mathrm{rfb} .1 \mathrm{bis}$ ( $5^{\prime}$-ATACCGACGACGCCGATCT G-3') and rfbO25b.r (5' ${ }^{\prime}$-TGCTATTCATTATGCGCAG C-3') $[18,19]$. The sequence type was determined through multilocus sequence typing (MLST) by using the Achtman scheme (http://mlst.warwick.ac.uk/mlst/ dbs/Ecoli) [20]. blaCTX-M groups 1, 2, and 9 were detected through multiplex polymerase chain reactions by using specific primers, as previously described [21]. Furthermore, specific polymerase chain reactions were performed to detect the common group 9 variant (CTX-M-14) and group 1 variant (CTX-M-15) [19, 20].

\section{Statistical analysis}

All statistical analyses were performed using Stata Version 12.1 (StataCorp., College Station, Texas, USA) statistical software package. Categorical data were analyzed using the chi-squared and Fisher exact tests.

\section{Results}

\section{Antimicrobial susceptibility testing}

Stool samples were collected from 255 children; E. coli was cultured from 169 children. Twelve children were excluded because they were receiving antibiotic treatment or were hospitalized in the 3 months before specimen collection. Among 157 E. coli isolates, 25.5\% (40/157) were susceptible to all tested antibiotics. 
Furthermore, 70.1\% (110/157), 65.6\% (103/157), 47.1\% (74/157), and $32.5 \%(51 / 157)$ of the isolates were nonsusceptible to ampicillin, amoxicillin-clavunate, TMP-SMZ, and cefazolin, respectively. MDR E. coli accounted for $36.9 \%$ of all isolates (58/157; Table 1), among which $17.2 \%$ (27/157), $14.0 \%$ (22/157), and 5.7\% (9/157) were nonsusceptible to at least 1 agent in 3,4 , and 5 antimicrobial categories, respectively.

Thirteen E. coli isolates produced ESBL; 11 were MDR $E$. coli. Twenty-nine E. coli isolates were nonsusceptible to ciprofloxacin; 25 were MDR E. coli (Table 2).

\section{MLST of $E$. coli isolates}

Twenty-six E. coli isolates were O25b positive, among which 9 were MDR E. coli and 9 were ESBL producers. Among 58 MDR E. coli isolates, 7 were O25b-ST131 positive and ESBL producers. Only 1 isolate was positive for O25b-ST131 but was not MDR and did not produce ESBL. Seven isolates with $\mathrm{O} 25 \mathrm{~b}-\mathrm{ST} 131$ positivity were MDR $E$. coli, among which only 1 was susceptible to ciprofloxacin. Furthermore, 1 isolate with O25b-ST131 positivity was not MDR and was susceptible to ciprofloxacin. Compared with the non-ESBL and ciprofloxacin-susceptible groups, the ESBL and ciprofloxacin-nonsusceptible groups had significantly higher rates of O25b-ST131 positivity ( $4.2 \%$ vs 53.9 and $4.70 \%$ vs $24.1 \%$, respectively; Table 3 ).
Table 2 Number of E. coli isolates with/without ESBL, susceptible/nonsusceptible ciprofloxacin, O25b, and ST131 in children's stool

\begin{tabular}{llllll}
\hline & \multicolumn{2}{l}{ ST 131 } & & \multicolumn{2}{l}{ Non ST 131 } \\
\cline { 2 - 3 } & O25b & NonO25b & & O25b & NonO25b \\
\hline ESBL $+(n=13)$ & 7 & 4 & 2 & 0 \\
ESBL $-(n=144)$ & 3 & 3 & 14 & 124 \\
Cipro R $(n=29)$ & 6 & 1 & 4 & 18 \\
Cipro S $(n=128)$ & 4 & 2 & 12 & 110 \\
\hline
\end{tabular}

\section{blaCTX-M gene study}

Five of the 13 (38.5\%) ESBL-producing E. coli belonged to blaCTX-M group 9, among which were all CTXM-14, and $4(80 \%)$ were confirmed as ST131. Three O25b ESBL-producing $E$. coli contained the CTX-M group 1 genes that were confirmed to be CTX-M- $(3,15)$, and they were all ST131 (Table 4).

\section{Discussion}

Antimicrobial resistance in commensal flora is a serious threat because a very highly populated ecosystem, such as the gut, may become a source of additional intestinal infections at a later stage. These infections may subsequently spread to other hosts or transfer genetic resistance elements to other members of the microbiota,

Table 1 Antimicrobial nonsusceptibility rates of E. coli in the stools of community children in Southern Taiwan

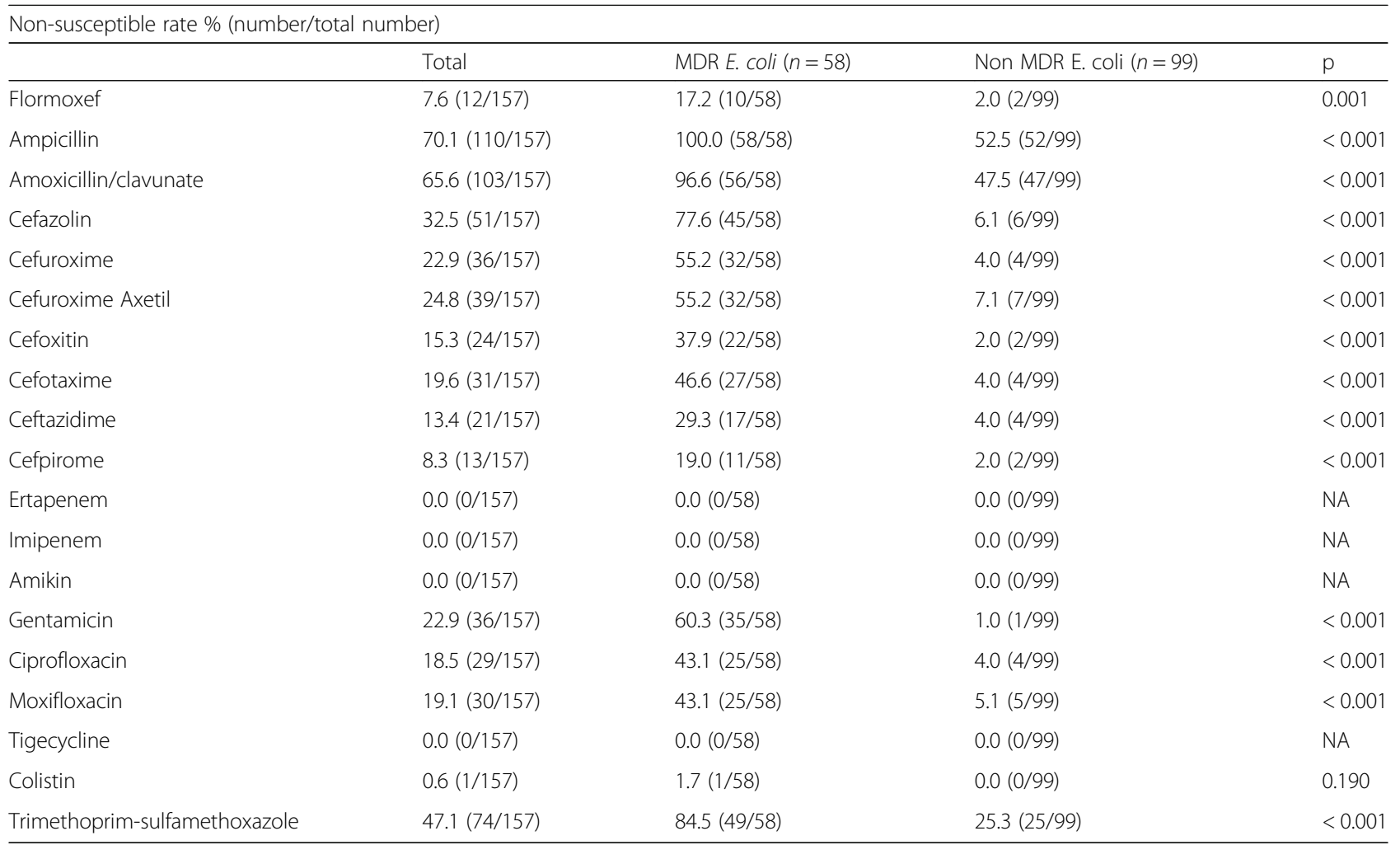


Table 3 Rates of E. coli ST131 positivity of the ESBL, non-ESBL, ciprofloxacin-nonsusceptible, ciprofloxacin-susceptible, MDR, and non-MDR groups

\begin{tabular}{ll}
\hline & $\begin{array}{l}\text { ST131 positive } \% \\
\text { (number/total number) }\end{array}$ \\
\hline ESBL $n=13$ & $53.6 \%(7 / 13)$ \\
Non-ESBL $n=144$ & $4.2 \%(6 / 144)$ \\
$P$ & $<0.001$ \\
$\begin{array}{l}\text { Ciprofloxacin non-susceptible } \\
(n=29)\end{array}$ & $24.1 \%(7 / 29)$ \\
$\begin{array}{l}\text { Ciprofloxacin susceptible } \\
(n=128)\end{array}$ & $4.7 \%(6 / 128)$ \\
$P$ & \\
MDR $(n=58)$ & 0.003 \\
Non-MDR $(n=99)$ & $13.8 \%(8 / 58)$ \\
$P$ & $5.1 \%(5 / 99)$ \\
\hline
\end{tabular}

including pathogens [22]. A major public health concern is that with the increasing number of individuals carrying these resistant strains as part of their normal flora, the probability of acquiring clinical infections, either in the community or hospital, increases. Several studies have addressed the prevalence of resistant $E$. coli isolated from the stools of children [23-38] (Table 5). The rates of resistance to first-line antimicrobial agents, namely ampicillin, TMP-SMZ, and first-generation cephalosporins, were $16-100 \%, 8-100 \%$, and $6-10 \%$, respectively. Furthermore, the rate of resistance to ciprofloxacin was $0-53 \%$, and $2.6-20.3 \%$ of E. coli were ESBL producers. The aforementioned studies had varied methodologies, study periods, sample sizes, and demographics and should thus be compared cautiously. However, the importance of surveillance of resistant strains must be addressed to achieve a holistic strategy for resistance control.
The present study is the first to investigate the fecal carriage of MDR E. coli in community children in Taiwan. In this study, high rates of nonsusceptibility to commonly used antimicrobial agents, such as ampicillin, amoxicillin + clavulanate, TMP-SMZ, and cefazolin (70, 65.6, 47.1, and $32.5 \%$, respectively) were obtained. The rate of nonsusceptibility to ciprofloxacin was approximately $18.3 \%$. By contrast, the rate of nonsusceptibility to relatively rarely used antibiotics, which could only be prescribed by infection doctors in medical centers in Taiwan, such as imipenem, amikacin, tigecycline, and colistin, was $0 \%$. This phenomenon could be explained by the selective pressure induced by the intensive use of antibiotics commonly used in both humans and nonhumans. Therefore, under the pressure of excessive antibiotic use, genes, such as blaCTX-M, spread amongst different bacterial species and strains through horizontal gene transfer and thus contribute to the rapid dispersal of antibiotic resistance in the community [39]. In our study, MDR E. coli accounted for $36.9 \%$ of all isolates. Although this percentage is lower than that reported in Guinea-Bissau [33], the rates of nonsusceptibility to amoxicillin + clavulanate and ciprofloxacin and of ESBL-producing E. coli are still higher than those reported in developed countries $[28,36]$.

In our previous study of 111 infants who were hospitalized for UTIs caused by ESBL-producing E. coli, O25b-ST131 was identified in $65 \%$ of isolates [40]. Among the 111 patients, 92 isolates belonged to blaCTX-M group 9, and most were CTXM-14. Furthermore, most patients with bacteremia or UTIs were previously healthy and did not exhibit any apparent risk factors, including previous antimicrobial use, hospitalization, neonatal infection, and underlying disease. Only $30 \%$ of the infants with UTIs caused by this clone had identifiable risk factors. Our findings support that most

Table 4 Number of CTX-M genes detected in O25b and non-O25b ESBL-producing E. coli and ESBL-nonproducing E. coli

\begin{tabular}{|c|c|c|c|c|c|c|c|c|c|c|c|c|c|c|c|c|c|c|c|c|}
\hline \multirow[t]{3}{*}{ E. coli } & \multicolumn{20}{|c|}{ Total number: 157} \\
\hline & \multicolumn{10}{|c|}{ ESBL } & \multicolumn{10}{|c|}{ Non-ESBL } \\
\hline & \multicolumn{10}{|l|}{13} & \multicolumn{10}{|c|}{144} \\
\hline Type & \multicolumn{5}{|l|}{ O } & \multicolumn{5}{|l|}{ NO } & \multicolumn{5}{|l|}{$\mathrm{O}$} & \multicolumn{5}{|l|}{ NO } \\
\hline No. & \multicolumn{5}{|l|}{9} & \multicolumn{5}{|l|}{4} & \multicolumn{5}{|l|}{17} & \multicolumn{5}{|l|}{127} \\
\hline ST & 69 & 73 & 95 & 131 & NS & 69 & 73 & 95 & 131 & NS & 69 & 73 & 95 & 131 & NS & 69 & 73 & 95 & 131 & NS \\
\hline No. & 0 & 0 & 0 & 7 & 2 & 0 & 0 & 0 & 0 & 4 & 1 & 0 & 0 & 3 & 13 & 9 & 5 & 5 & 3 & 105 \\
\hline CTX-M-G1 & 0 & 0 & 0 & 0 & 0 & 0 & 0 & 0 & 0 & 0 & 0 & 0 & 0 & 0 & 0 & 0 & 0 & 0 & 1 & 1 \\
\hline CTX-M-G1 CTX-M- $(3,15)$ & 0 & 0 & 0 & 3 & 0 & 0 & 0 & 0 & 0 & 0 & 0 & 0 & 0 & 0 & 0 & 0 & 0 & 0 & 0 & 1 \\
\hline CTX-M-G2 & 0 & 0 & 0 & 0 & 0 & 0 & 0 & 0 & 0 & 0 & 0 & 0 & 0 & 0 & 0 & 0 & 0 & 0 & 0 & 0 \\
\hline CTX-M-G8 & 0 & 0 & 0 & 0 & 0 & 0 & 0 & 0 & 0 & 1 & 0 & 0 & 0 & 0 & 0 & 0 & 0 & 0 & 0 & 0 \\
\hline CTX-M-G9 CTX-M-14 & 0 & 0 & 0 & 4 & 0 & 0 & 0 & 0 & 0 & 1 & 1 & 0 & 0 & 1 & 2 & 2 & 0 & 0 & 0 & 5 \\
\hline Non-CTX-M-group-(1,2,8,9) & 0 & 0 & 0 & 0 & 2 & 0 & 0 & 0 & 0 & 2 & 0 & 0 & 0 & 2 & 11 & 7 & 5 & 5 & 2 & 98 \\
\hline
\end{tabular}

O, O25b; NO, Non O25b; NS, Non ST. 
Table 5 Summary of 20 studies on the fecal carriage of E. coli in community children from different countries

\begin{tabular}{|c|c|c|c|c|c|}
\hline $\begin{array}{l}\text { Country } \\
\text { (published years) }\end{array}$ & First author & Study population & Setting & $\begin{array}{l}\text { Sample } \\
\text { size }\end{array}$ & Prevalence of resistance \\
\hline $\begin{array}{l}\text { Houston, Tex USA } \\
\text { (1987) [23] }\end{array}$ & Reves RR & Children & Cross-section, day-care centers & 79 & $\begin{array}{l}\text { trimethoprim: } 37 \% \text {; } \\
\text { ampicillin: } 70 \%\end{array}$ \\
\hline Bolivia (1998) [24] & Bartoloni A & aged 6-72 months & $\begin{array}{l}\text { healthy children; } \\
\text { community-based }\end{array}$ & 296 & $\begin{array}{l}\text { Ampicillin: } 97 \% \\
\text { TMP/SMX: } 94 \% \\
\text { Cephalothin:10\% } \\
\text { Tetracycline: } 92 \% \\
\text { Ciprofloxacin: } 0 \%\end{array}$ \\
\hline $\begin{array}{l}\text { Shanghai, China } \\
\text { (1998) [25] }\end{array}$ & Zhang XL & $\begin{array}{l}\text { Group A: Children of } \\
5-6 \text { years } \\
\text { Group B: Children of } \\
10-11 \text { years }\end{array}$ & $\begin{array}{l}\text { A: Nursery school } \\
\text { B: Primary school }\end{array}$ & $\begin{array}{l}\text { A: } 30 \\
\text { B: } 54\end{array}$ & $\begin{array}{l}\text { A: } \\
\text { Ampicillin: } 93.3 \% \\
\text { Trimethoprim: } 100 \% \\
\text { Ciprofloxacin: } 43.3 \% \\
\text { B: } \\
\text { Ampicillin: 100\% } \\
\text { Trimethoprim: } 100 \% \\
\text { Ciprofloxacin: } 53.7 \%\end{array}$ \\
\hline Mexican (2003) [26] & Zaidi MB & $\begin{array}{l}\text { healthy children } \\
\text { (1 month to } 12 \text { years) }\end{array}$ & $\begin{array}{l}\text { day care centers or } \\
\text { kindergartens }\end{array}$ & 276 & $\begin{array}{l}\text { nalidixic acid: } 54 \% \\
\text { ciprofloxacin: } 18.5 \%\end{array}$ \\
\hline $\begin{array}{l}\text { Bolivia and Peru } \\
\text { (2006) [27] }\end{array}$ & Bartoloni A & $\begin{array}{l}\text { children } \\
\text { (aged } 6 \text { to } 72 \text { months) }\end{array}$ & $\begin{array}{l}\text { Health children in four } \\
\text { urban area }\end{array}$ & 3174 & $\begin{array}{l}\text { Ampicillin: } 95 \% \text {, } \\
\text { trimethoprim-sulfamethoxazole: } 94 \% \\
\text { nalidixic acid: } 35 \% \\
\text { gentamicin: } 21 \% \\
\text { ciprofloxacin: } 18 \% \\
\text { ceftriaxone: } 0.1 \% \\
\text { amikacin: } 0.1 \%\end{array}$ \\
\hline Germany (2007) [28] & Lietzau S & $\begin{array}{l}\text { children aged } \\
6 \text { months to } 4 \text { years }\end{array}$ & $\begin{array}{l}\text { regular health screening } \\
\text { or an acute infection }\end{array}$ & 884 & $\begin{array}{l}\text { Ampicillin: } 16.6 \% \\
\text { amoxicillineclavulanic acid: } 8 \% \\
\text { cotrimoxazole: } 8.7 \% \\
\text { Nalidixic acid: } 2.0 \% \\
\text { Levofloxacin: } 0.4 \%\end{array}$ \\
\hline India (2009) [29] & Seidman JC & aged $5-10$ years & primary school children & 119 & $\begin{array}{l}\text { Cefazoline: } 6.7 \%(8 / 119) \\
\text { ampicillin: } 38.7 \%(46 / 119) \\
\text { cotrimoxazole: } 37.0 \%(44 / 119) \\
\text { Ciprofloxacin: } 12.6 \%(15 / 119) \\
\text { Cefotaxime: } 4.2 \%(5 / 119)\end{array}$ \\
\hline Senegal (2009) [30] & Ruppé E & aged 1 to 11 years & healthy children & 20 & ESBL-producing: 10\% \\
\hline Portugal (2009) [31] & Guimaraes B & Aged 1 to 14 years & healthy children & 112 & ESBL-positive: $2.7 \%$ \\
\hline Vietnam (2012) [32] & Dyar OJ & $\begin{array}{l}\text { child aged } 6- \\
60 \text { months }\end{array}$ & rural children ( $1 \%$ with diarrhea) & 818 & $\begin{array}{l}\text { Ampicillin: } 65 \% \\
\text { co-trimoxazole: } 68 \% \\
\text { ciprofloxacin: }<1 \%\end{array}$ \\
\hline $\begin{array}{l}\text { Guinea-Bissau } \\
\text { (2012) [33] }\end{array}$ & Isendahl J & $\begin{array}{l}\text { children }<5 \text { years of } \\
\text { age }\end{array}$ & $\begin{array}{l}\text { fever or tachycardia attending } \\
\text { a pediatric emergency ward }\end{array}$ & 408 & ESBL-producing E coli: 20.34\% (83/408) \\
\hline Sweden (2013) [34] & Kaarme J & $\begin{array}{l}\text { Children } \\
\text { (range 11-66 months) } \\
66 \text { months }\end{array}$ & preschool & 313 & ESBL-producing E coli: 2.6\% (8/313) \\
\hline Libyan (2014) [35] & Ahmed SF & $\begin{array}{l}\text { children aged from } \\
3 \text { to } 12 \text { years }\end{array}$ & $\begin{array}{l}\text { Diarrhea attending outpatient } \\
\text { clinics }\end{array}$ & 134 & $\begin{array}{l}\text { Ampicillin: } 78.4 \% \\
\text { Amoxicillin/Clavulanic: } 64.2 \% \\
\text { TMP/SMZ: } 61.9 \% \\
\text { Cefotaxime: } 20.2 \% \\
\text { Ciprofloxacin: } 5.2 \% \\
\text { ESBL-producing E coli: } 13.4 \%(18 / 134)\end{array}$ \\
\hline France (2014) [36] & Blanc V & $\begin{array}{l}\text { Children } \\
\text { ( } 3 \text { and } 40 \text { months) }\end{array}$ & Day-care center & 419 & ESBL-producing E coli: 6.4\% \\
\hline Spain (2014) [37] & $\begin{array}{l}\text { Fernández-Reyes } \\
\text { M }\end{array}$ & $\begin{array}{l}\text { children at the ages } \\
\text { of } 8,12 \text {, and } 16 \text { months }\end{array}$ & healthy children in the community & 125 & $\begin{array}{l}\text { ESBL-producing E coli: } 24 \% \text { of } 125 \text { children } \\
\text { and } 10.7 \% \text { of the } 318 \text { fecal samples }\end{array}$ \\
\hline $\begin{array}{l}\text { Lao People's } \\
\text { Democratic Republic } \\
\text { (2015) [38] }\end{array}$ & Stoesser N & $\begin{array}{l}\text { children } \leq 6 \text { years } \\
\text { of age }\end{array}$ & preschool childcare facilities & 397 & $\begin{array}{l}\text { ESBL-producing E coli: } 19.65 \% \text { (78/397) } \\
\text { Amoxicillin/clavulanate: 10.33\% (41/397) } \\
\text { Co-trimoxazole: } 14.61 \%(58 / 397) \\
\text { Cefotaxime: } 19.4 \%(77 / 397) \\
\text { Ofloxacin: } 3.78 \%(15 / 397)\end{array}$ \\
\hline
\end{tabular}


drug-resistant $E$. coli infections are community-not hospital-acquired [17, 40, 41]. Furthermore, we previously evaluated $E$. coli isolated from several rivers in Southern Taiwan and revealed that the most commonly isolated ESBL-producing $E$. coli clonal complexes were ST10 and ST58 and not the major clone ESBL-producing E. coli ST131, which causes community-acquired infections both worldwide and in Taiwan [42]. In contrast, in the present study, ST131 (7/13) was the most common ESBL-producing E. coli clone in the stools of children.

In the present study, $13 \mathrm{E}$. coli isolates produced ESBL, of which 11 were MDR E. coli and 69\% (9/13) were nonsusceptible to ciprofloxacin. These results corroborate the finding that the plasmid-mediated transfer of ESBLs enhances resistance to non- $\beta$-lactams, such as quinolones, because plasmids can harbor genes that confer resistance to multiple antibiotic groups [43, 44]. Furthermore, compared with the non-ESBL and ciprofloxacin-susceptible groups, the ESBL and ciprofloxacin-nonsusceptible groups yielded significantly higher rates of ST131 positivity. The rates of ST131 positivity tended to be higher in the MDR group than in the non-MDR group ( $13.8 \%$ vs $5.1 \%, p=0.073$ ). These results also demonstrated that the E. coli ST131 clone might be associated with antimicrobial resistance.

Our study has some limitations. First, we used a hospital-based design; therefore, our findings are not generalizable to healthy children in the community because of potential selection bias in patient inclusion. Furthermore, the fecal samples in this study were collected within 3 days of hospitalization. Transmission leading to asymptomatic carriage may occur within less than 3 days after hospital admission. Second, to prevent risk factors from affecting the fecal carriage of resistant $E$. coli, patients who received antibiotic treatment or were hospitalized in the 3 months before specimen collection as well as those with underlying diseases were excluded, leading to the possible underestimation of antimicrobial resistance. Third, because the diseases of the enrolled patients were not further classified, we could not determine whether the different diseases affected the fecal carriage and antimicrobial resistance rate of $E$. coli. For example, including children with gastroenteritis may cause bias because the infection may lead to a temporary change in intestinal flora, with a dominance of pathogenic bacteria. In addition, identifying $E$. coli based on the blue color of the CHROMagar $^{\text {Tax }}$ ECC may cause misidentification because other species, such as Enterobacter, Klebisella, and Citrobacter, also showed a blue color, which may overestimate the prevalence of $E$. coli. However, selecting one isolate per sample for testing may have underestimated the prevalence of $E$. coli in this study.

\section{Conclusion}

This study is the first to report a high rate $(37 \%)$ of MDR E. coli in the stools of community children in Southern Taiwan. Twenty-nine E. coli isolates (18.5\%) were not susceptible to ciprofloxacin, and approximately 8.3\% of E. coli produced ESBL. O25b-ST131 (7/13) was the most common ESBL-producing $E$. coli clonal group in the stools of children. These results highlight the importance of establishing an antibiotic stewardship and infection control programs to reduce inappropriate antibiotic use and limit the transmission of MDR E. coli.

\section{Additional file}

Additional file 1: Table S1. Minimal inhibitory concentration breakpoints for Enterobacteriaceae. (DOCX $16 \mathrm{~kb}$ )

\section{Abbreviations}

E. coli: Escherichia coli; ESBL: Extended-spectrum $\beta$-lactamase; MDR: Multidrugresistant; MLST: Multilocus sequence typing; TMP-SMZ: Trimethoprimsulfamethoxazole; UTIs: Urinary tract infections

\section{Funding}

This study was supported by grants from Kaohsiung Veterans General Hospital, Taiwan (VGHNSU104-004 to I-Fei Huang) and the Ministry of Science and Technology, Taiwan (MOST 104-2314-B-075B-003 -MY3 to Ming-Fang Cheng). The funders played no role in the study design, data collection and interpretation, or decision to publish the study.

\section{Availability of data and materials}

The datasets generated and/or analysed during the current study will be provided by the corresponding author on reasonable request.

\section{Authors' contributions}

IFH and WYL contributed equally to this study. IFH was a major contributor in manuscript drafting. WYL performed article search. MFC and JLW performed data analysis and interpretation. HHH, WCC, and YTS collected stool samples. $\mathrm{CHH}$ and WYH performed microbiological laboratory procedures. YJH performed statistical analysis. All authors have read and approved the manuscript and the order of the authors.

\section{Ethics approval and consent to participate}

This study was approved by the Institutional Review Board of Kaohsiung Veterans General Hospital (VGHKS14-CT3-09). All participants (their parent or legal guardian in the case of children aged less than 16 years) provided written informed consent.

\section{Competing interests}

The authors declare that they have no competing interests.

\section{Publisher's Note}

Springer Nature remains neutral with regard to jurisdictional claims in published maps and institutional affiliations.

\section{Author details}

${ }^{1}$ Department of Pediatrics, Kaohsiung Veterans General Hospital, No. 386, Ta-Chung 1st Road, Kaohsiung 81362, Taiwan. ${ }^{2}$ School of Medicine, National Yang-Ming University, Taipei, Taiwan. ${ }^{3}$ Chung Hwa University of Medical Technology, Tainan, Taiwan. ${ }^{4}$ Department of Pediatrics, Kaohsiung Municipal United Hospital, Kaohsiung, Taiwan. ${ }^{5}$ Department of Internal Medicine, College of Medicine, National Cheng Kung University Hospital, National Cheng Kung University, Tainan, Taiwan. ${ }^{6}$ Department of Medicine, College of Medicine, National Cheng Kung University, Tainan, Taiwan. ${ }^{7}$ Department of Chemical Engineering and Institute of Biotechnology and Chemical Engineering, I-Shou University, Kaohsiung, Taiwan. ${ }^{8}$ Division of 
Gastroenterology, Department of Medicine, Kaohsiung Veterans General Hospital, Kaohsiung, Taiwan. ${ }^{9}$ Fooyin University, Kaohsiung, Taiwan.

\section{Received: 29 September 2016 Accepted: 23 May 2018 Published online: 15 June 2018}

\section{References}

1. Mandell GL, Bennett JE, Mandell DR. Douglas, and Bennett's principles and practice of infectious diseases. 7th ed. Philadelphia, PA: Churchill Livingstone/Elsevier; 2010.

2. Cosgrove SE, Carmeli Y. The impact of antimicrobial resistance on health and economic outcomes. Clin Infect Dis. 2003;36(11):1433-7.

3. Nicolas-Chanoine MH, Blanco J, Leflon-Guibout V, Demarty R, Alonso MP, Canica MM, et al. Intercontinental emergence of Escherichia coli clone O25: H4-ST131 producing CTX-M-15. J Antimicrob Chemother. 2008;61(2):273-81.

4. Coque TM, Novais Â, Carattoli A, Poire L, Pitout J, Peixe L, et al. Dissemination of clonally related Escherichia coli strains expressing extended-spectrum betalactamase CTX-M-15. Emerg Infect Dis. 2008;14(2):195-200.

5. Lau SH, Reddy S, Cheesbrough J, Bolton FJ, Willshaw G, Cheasty T, et al. Major uropathogenic Escherichia coli strain isolated in the northwest of England identified by multilocus sequence typing. J Clin Microbiol. 2008;46(3):1076-80.

6. Rogers BA, Sidjabat HE, Paterson DL. Escherichia coli O25b-ST131: a pandemic, multiresistant, community-associated strain. J Antimicrob Chemother. 2011;66(1):1-14.

7. Johnson JR, Johnston B, Clabots C, Kuskowski MA, Pendyala S, Debroy C, et al. Escherichia coli sequence type ST131 as an emerging fluoroquinoloneresistant uropathogen among renal transplant recipients. Antimicrob Agents Chemother. 2010;54(1):546-50.

8. Uchida Y, Mochimaru T, Morokuma Y, Kiyosuke M, Fujise M, Eto F, et al. Clonal spread in eastern Asia of ciprofloxacin-resistant Escherichia coli serogroup $\mathrm{O} 25$ strains, and associated virulence factors. Int J Antimicrob Agents. 2010;35(5):444-50.

9. Caprioli A, Busani L, Martel JL, Helmuth R. Monitoring of antibiotic resistance in bacteria of animal origin: epidemiological and microbiological methodologies. Int J Antimicrob Agents. 2000;14(4):295-301.

10. Karami N, Martner A, Enne VI, Swerkersson S, Adlerberth I, Wold AE. Transfer of an ampicillin resistance gene between two Escherichia coli strains in the bowel microbiota of an infant treated with antibiotics. J Antimicrob Chemother. 2007;60(5):1142-5.

11. Blake DP, Hillman K, Fenlon DR, Low JC. Transfer of antibiotic resistance between commensal and pathogenic members of the Enterobacteriaceae under ideal conditions. J Appl Microbiol. 2003;95(3):428-36.

12. Oteo J, Perez-Vazquez M, Campos J. Extended-spectrum [beta]-lactamase producing Escherichia coli: changing epidemiology and clinical impact. Curr Opin Infect Dis. 2010;23(4):320-6.

13. Rivard-Yazigi L, Zahar JR, Le Guillou S, Chalouhi C, Lecuyer H, Bureau C, Nassif X, Gendrel D, Abadie V. Risk factors associated with extendedspectrum $\beta$-lactamase-producing Enterobacteriaceae carriage at admission in an infant cohort at a tertiary teaching hospital in France. Am J Infect Control. 2013:41(9):844-5.

14. Alonso JL, Soriano A, Carbajo O, Amoros I, Garelick H. Comparison and recovery of Escherichia coli and thermotolerant coliforms in water with a chromogenic medium incubated at 41 and 445 degrees C. Appl Environ Microbiol. 1999:65(8):3746-9.

15. Clinical Laboratory Standards Institute. Performance standards for antimicrobial susceptibility testing, 19th Informational supplement M100S19. Wayne, PA: Clinical Laboratory Standards Institute; 2009.

16. Magiorakos AP, Srinivasan A, Carey RB, Carmeli Y, Falagas ME, Giske CG, Harbarth S, Hindler JF, Kahlmeter G, Olsson-Liljequist B, Paterson DL, Rice LB, Stelling J, Struelens MJ, Vatopoulos A, Weber JT, Monnet DL. Multidrugresistant, extensively drug-resistant and pandrug-resistant bacteria: an international expert proposal for interim standard definitions for acquired resistance. Clin Microbiol Infect. 2012;18(3):268-81.

17. Chung HC, Lai CH, Lin JN, Huang CK, Liang SH, Chen WF, et al. Bacteremia caused by extended-spectrum-beta-lactamase-producing Escherichia coli sequence type ST131 and non-ST131 clones: comparison of demographic data, clinical features, and mortality. Antimicrob Agents Chemother. 2012; 56(2):618-22.

18. Clermont O, Lavollay M, Vimont S, Deschamps C, Forestier C, Branger C, et al. The CTX-M-15-producing Escherichia coli diffusing clone belongs to a highly virulent B2 phylogenetic subgroup. J Antimicrob Chemother. 2008; 61(5):1024-8.

19. Sidjabat HE, Paterson DL, Adams-Haduch JM, Ewan L, Pasculle AW, Muto CA, et al. Molecular epidemiology of CTX-M-producing Escherichia coli isolates at a tertiary medical center in western Pennsylvania. Antimicrob Agents Chemother. 2009:53(11):4733-9.

20. Chia JH, Chu C, Su LH, Chiu CH, Kuo AJ, Sun CF, et al. Development of a multiplex PCR and SHV melting-curve mutation detection system for detection of some SHV and CTX-M beta-lactamases of Escherichia coli, Klebsiella pneumoniae, and Enterobacter cloacae in Taiwan. J Clin Microbiol. 2005;43(9):4486-91.

21. Dallenne C, Da Costa A, Decre D, Favier C, Arlet G. Development of a set of multiplex PCR assays for the detection of genes encoding important betalactamases in Enterobacteriaceae. J Antimicrob Chemother. 2010;65(3):490-5.

22. Macpherson AJ, Harris NL. Interactions between commensal intestinal bacteria and the immune system. Nat Rev Immunol. 2004;4(6):478-85.

23. Reves RR, Murray BE, Pickering LK, Prado D, Maddock M, Bartlett AV 3rd. Children with trimethoprim- and ampicillin-resistant fecal Escherichia coli in day care centers. J Infect Dis. 1987;156(5):758-62.

24. Bartoloni A, Cutts F, Leoni S, Austin CC, Mantella A, Guglielmetti P, et al. Patterns of antimicrobial use and antimicrobial resistance among healthy children in Bolivia. Tropical Med Int Health. 1998;3(2):116-23.

25. Zhang XL, Wang F, Zhu DM, Wu S, Wu PC, Chen YD, et al. The carriage of Escherichia coli resistant to antibiotics in healthy populations in shanghai. Biomed Environ Sci. 1998;11(4):314-20.

26. Zaidi MB, Zamora E, Diaz P, Tollefson L, Fedorka-Cray PJ, Headrick ML. Risk factors for fecal quinolone-resistant Escherichia coli in Mexican children. Antimicrob Agents Chemother. 2003:47(6):1999-2001.

27. Bartoloni A, Pallecchi L, Benedetti M, Fernandez C, Vallejos Y, Guzman E, et al. Multidrug-resistant commensal Escherichia coli in children, Peru and Bolivia. Emerg Infect Dis. 2006;12(6):907-13.

28. Lietzau S, Raum E, von Baum H, Marre R, Brenner H. Household contacts were key factor for children's colonization with resistant Escherichia coli in community setting. J Clin Epidemiol. 2007;60(11):1149-55.

29. Seidman JC, Anitha KP, Kanungo R, Bourgeois AL, Coles CL. Risk factors for antibiotic-resistant E. coli in children in a rural area. Epidemiol Infect. 2009; 137(6):879-88.

30. Ruppe E, Woerther PL, Diop A, Sene AM, Da Costa A, Arlet G, et al. Carriage of CTX-M-15-producing Escherichia coli isolates among children living in a remote village in Senegal. Antimicrob Agents Chemother. 2009;53(7):3135-7.

31. Guimaraes B, Barreto A, Radhouani H, Figueiredo N, Gaspar E, Rodrigues J, et al. Genetic detection of extended-spectrum beta-lactamase-containing Escherichia coli isolates and vancomycin-resistant enterococci in fecal samples of healthy children. Microbial Drug Resist. 2009;15(3):211-6.

32. Dyar OJ, Hoa NQ, Trung NV, Phuc HD, Larsson M, Chuc NT, et al. High prevalence of antibiotic resistance in commensal Escherichia coli among children in rural Vietnam. BMC Infect Dis. 2012;12:92-9.

33. Isendahl J, Turlej-Rogacka A, Manjuba C, Rodrigues A, Giske CG, Naucler P. Fecal carriage of ESBL-producing E. coli and K. pneumoniae in children in Guinea-Bissau: a hospital-based cross-sectional study. PLoS One. 2012; 7(12):e51981.

34. Kaarme J, Molin Y, Olsen B, Melhus A. Prevalence of extended-spectrum beta-lactamase-producing Enterobacteriaceae in healthy Swedish preschool children. Acta Paediatr. 2013;102(6):655-60.

35. Ahmed SF, Ali MMM, Mohamed ZK, Moussa TA, Klena JD. Fecal carriage of extended-spectrum $\beta$-lactamases and AmpC-producing Escherichia coli in a Libyan community. Ann Clin Microb Antimicrob. 2014;13:22-9.

36. Blanc V, Leflon-Guibout V, Blanco J, Haenni M, Madec JY, Rafignon G, et al. Prevalence of day-care Centre children (France) with faecal CTX-Mproducing Escherichia coli comprising O25b:H4 and O16:H5 ST131 strains. J Antimicrob Chemother. 2014;69(5):1231-7.

37. Fernandez-Reyes M, Vicente D, Gomariz M, Esnal O, Landa J, Onate E, et al. High rate of fecal carriage of extended-spectrum-beta-lactamase-producing Escherichia coli in healthy children in Gipuzkoa, northern Spain. Antimicrob Agents Chemother. 2014;58(3):1822-4.

38. Stoesser N, Xayaheuang S, Vongsouvath M, Phommasone K, Elliott I, Del Ojo Elias C, et al. Colonization with Enterobacteriaceae producing ESBLs in children attending pre-school childcare facilities in the Lao People's Democratic Republic. J Antimicrob Chemother. 2015;70(6):1893-7.

39. Hawkey PM, Jones AM. The changing epidemiology of resistance. J Antimicrob Chemother. 2009;64(Suppl 1):i3-10. 
40. Cheng MF, Chen WL, Hung WY, Huang IF, Chiou YH, Chen YS, et al. Emergence of extended spectrum-beta-lactamase-producing Escherichia coli O25b-ST131: a major community-acquired uropathogen in infants. Pediatr Infect Dis J. 2015;34(5):469-75.

41. Wu YH, Cheng MF, Lai CH, Lin HH, Hung CH, Wang JL. The role of sequence type (ST) 131 in adult community-onset non-ESBL-producing Escherichia coli bacteraemia. BMC Infect Dis. 2014;14:579.

42. Chen PA, Hung $\mathrm{CH}$, Huang PC, Chen JR, Huang IF, Chen WL, et al. Characteristics of CTX-M extended-spectrum beta-lactamase-producing Escherichia coli strains isolated from multiple rivers in southern Taiwan. Appl Environ Microbiol. 2016;82(6):1889-97.

43. Levy SB, Marshall B. Antibacterial resistance worldwide: causes, challenges and responses. Nat Med. 2004;10(12 Suppl):S122-9.

44. Mammeri H, Van De Loo M, Poirel L, Martinez-Martinez L, Nordmann P. Emergence of plasmid-mediated quinolone resistance in Escherichia coli in Europe. Antimicrob Agents Chemother. 2005;49(1):71-6.

Ready to submit your research? Choose BMC and benefit from:

- fast, convenient online submission

- thorough peer review by experienced researchers in your field

- rapid publication on acceptance

- support for research data, including large and complex data types

- gold Open Access which fosters wider collaboration and increased citations

- maximum visibility for your research: over $100 \mathrm{M}$ website views per year

At BMC, research is always in progress.

Learn more biomedcentral.com/submissions 